\title{
ANALISIS KELAYAKAN PENGEMBANGAN USAHA PENGOLAHAN KERUPUK IKAN LELE CLIPSS CATFISH CHIPS DI KOTA BOGOR
}

\author{
Hammad Akram1), dan Netti Tinaprilla2) \\ 1)Program Sarjana Agribisnis, Fakultas Ekonomi dan Manajemen Institut Pertanian Bogor \\ 2)Departemen Agribisnis, Fakultas Ekonomi dan Manajemen, Institut Pertanian Bogor \\ Jl. Kamper Wing 4 Level 5 Kampus IPB Dramaga, Indonesia \\ 1)e-mail: ikerakram@gmail.com
}

(Diterima 8 Juli 2020 / Disetujui 3 Agustus 2020)

\begin{abstract}
Catfish cracker processing business has enormous potential to be developed for several reasons, namely the high supply of catfish, the lack of utilization of catfish supply, and the increasing consumption trend of crackers. Clipss Catfish Chips is a catfish cracker processing business whose business development plan in the form of increasing production capacity includes the procurement of production machinery and relocation of the production house. Clipss Catfish Chips will also conduct business legalities to support the business development process. This research was conducted to assess the long-term investment planning on the development plan that Clipss will do. Data processing and analysis used in this research include feasibility analysis of non-financial aspects and financial aspects and switching value analysis. Analysis of non-financial aspects was studied qualitatively with descriptive and quantitatively with a Likert scale. Analysis of the financial aspect was studied using a few investment criteria namely Net Present Value, Net Benefit-Cost Ratio, Internal Rate of Return, and Payback Period. The results of the feasibility analysis of non-financial and financial aspects indicate that business development is feasible to run. The results of the switching value analysis show that the decrease in the amount of production is more sensitive than the increase in the price of fish and packaging.
\end{abstract}

Keywords: business development, catfish, cracker, feasibility study

\begin{abstract}
ABSTRAK
Usaha pengolahan kerupuk ikan lele memiliki potensi yang sangat besar untuk dikembangkan karena beberapa hal yaitu produksi ikan lele yang tinggi, pemanfaatan hasil produksi ikan lele yang minim, dan tren konsumsi kerupuk yang terus meningkat. Clipss Catfish Chips merupakan unit usaha pengolahan kerupuk ikan lele yang memiliki rencana pengembangan usaha berupa penambahan kapasitas produksi meliputi pengadaan mesin produksi dan pemindahan lokasi rumah produksi. Unit usaha Clipss Catfish Chips juga akan melakukan pengurusan legalitas usaha untuk menunjang proses pengembangan usaha. Penelitian ini bertujuan untuk menganalisis kelayakan investasi jangka panjang pada pengembangan usaha Clipss Catfish Chips yang akan dilakukan. Metode pengolahan dan analisis data yang digunakan dalam penelitian meliputi analisis kelayakan non finansial dan finansial serta analisis switching value. Analisis kelayakan non finansial dikaji secara kualitatif secara deskriptif dan kuantitatif dengan skala likert. Analisis kelayakan finansial dikaji dengan menggunakan kriteria investasi yaitu Net Present Value, Net Benefit Cost Ratio, Internal Rate of Return, dan Payback Period. Hasil analisis kelayakan pada aspek non finansial dan finansial menunjukkan bahwa pengembangan usaha layak untuk dijalankan. Hasil analisis switching value menunjukkan bahwa penurunan jumlah produksi lebih sensitif daripada kenaikan harga ikan dan kemasan.
\end{abstract}

Kata kunci: analisis kelayakan, ikan lele, kerupuk, pengembangan usaha

\section{PENDAHULUAN}

Ikan lele merupakan salah satu komoditas di sektor perikanan budidaya dengan tingkat pro- duksi tertinggi di Indonesia. Total produksi ikan lele menempati peringkat ketiga dengan jumlah produksi sebesar 719.619 ton di tahun 2015 (Budidyanto 2016). Hasil produksi ikan lele terus 
meningkat tiap tahunnya. Produksi ikan lele di tahun 2017 mampu meningkat dengan pesat mencapai angka 1,8 juta ton atau meningkat 131 persen dari tahun sebelumnya. Perkembangan produksi ikan lele tahun 2012 - 2017 dapat dilihat pada Gambar 1.

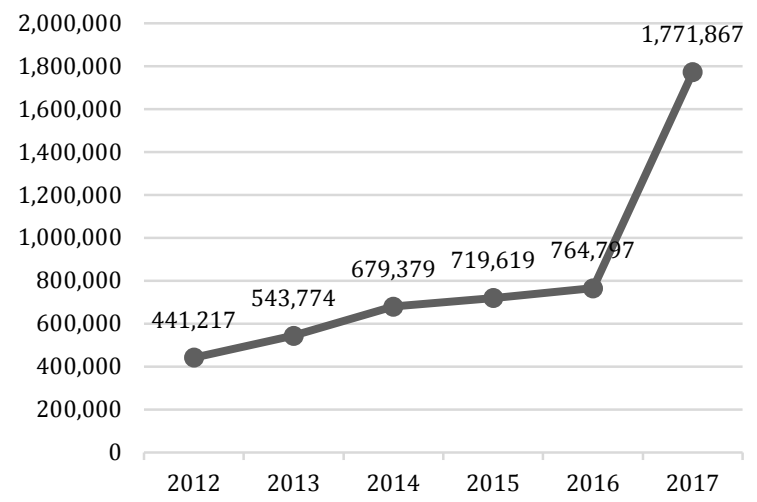

\section{Gambar 1. Perkembangan Produksi dan Konsumsi Ikan Lele di Indonesia Tahun 2012-2017}

Sumber : Ditjen Perikanan Budidaya KKP, 2018

Hasil produksi ikan lele tersebut mayoritas dijual dalam bentuk ikan hidup. Tercatat di Kabupaten Boyolali, Provinsi Jawa Tengah sebanyak 98 persen dari hasil produksi ikan lele dijual pada pedagang pengumpul dan pengecer yang kemudian diteruskan kepada gerai pecel lele dan gerai dagang di pasar tradisional. Sementara hanya 2 persen saja yang dijual kepada pengolah untuk kemudian diolah menjadi pangan olahan (Triyanti dan Safitri, 2012). Padahal industri pengolahan merupakan salah satu solusi atas permasalahan produk hasil perikanan seperti mudah rusak (perishable), tidak tahan lama, serta harga jual yang rendah.

Ikan lele dapat diolah menjadi berbagai macam bentuk olahan. Salah satu olahan ikan lele yang populer dan telah lama dikenal masyarakat adalah kerupuk. Menurut Kusumaningrum dan Sikin (2016), kerupuk pada umumnya dibuat dari tepung tapioka sebagai sumber pati dengan penambahan bumbu dan air memiliki kandungan gizi yang rendah. Penambahan gizi kerupuk dapat dilakukan dengan menambahkan daging ikan (Zulfahmi, et al. 2014). Sebagai salah satu komoditas perdagangan, permintaan kerupuk dalam negeri cukup tinggi, hasil Survei Ekonomi Nasional tahun 2018 menyebutkan rata-rata konsumsi kerupuk per kapita mencapai angka 0,192 Ons seminggu, angka tersebut meningkat drastis jika dibandingkan dengan rata-rata konsumsi kerupuk per kapita dalam seminggu di tahun sebelumnya. Rata-rata konsumsi kerupuk per kapita seminggunya dalam kurun waktu lima tahun terakhir dapat dilihat di Gambar 2.

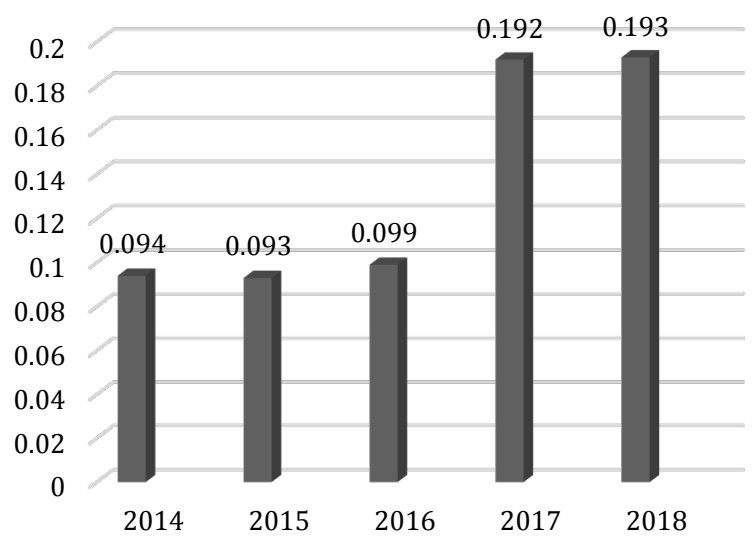

Gambar 2. Rata-rata Konsumsi Kerupuk per Kapita dalam Seminggu di Indonesia Tahun 2014-2018

Sumber : BPS, Susenas Maret 2014-2018 (diolah)

Salah satu perusahaan yang bergerak di bidang pengolahan dan pemasaran kerupuk ikan ialah Clipss Catfish Chips. Clipss Catfish Chips merupakan unit usaha skala mikro yang telah berjalan selama satu tahun lebih. Usaha ini berlokasi di Kecamatan Bogor Barat, Kota Bogor. Saat ini jumlah rata-rata produksi kerupuk ikan lele yang diproduksi unit usaha Clipss Catfish Chips adalah sebanyak 309 kemasan.

Pertumbuhan produksi ikan lele di Indonesia akan terus meningkat. Potensi bisnis pengolahan hasil perikanan kedepannya semakin menjanjikan mengingat pertumbuhan penduduk semakin meningkat dan permintaan produk olahan pangan termasuk hasil olahan perikanan akan meningkat. Pada tahun 2050 diperkirakan populasi global akan melebihi 9 miliar dan permintaan untuk produk makanan akan meningkat secara drastis 59-98 persen (Valin, et al. 2014).

Pengembangan industri pengolahan hasil perikanan merupakan salah satu prioritas dalam pembangunan nasional di sektor perikanan. Industri pengolahan hasil perikanan merupakan salah satu bagian dari agroindustri yang memiliki 
daya saing kuat dan mampu bertahan dalam jangka waktu yang lama. Tercatat pada tahun 2015 terdapat 718 Unit Pengolahan Ikan (UPI) berskala menengah-besar dan 60.885 unit berskala mikro-kecil (KKP 2015). Dari aspek pasar, tingkat permintaan yang diasumsikan dari tingkat konsumsi kerupuk dalam dua tahun terakhir meningkat pesat. Hal tersebut menandakan peluang pasar dalam negeri untuk produk kerupuk masih terbuka lebar.

Unit usaha Clipss Catfish Chips menyadari hal tersebut. Terlebih pemilik usaha menuturkan bahwa dalam kurun waktu beberapa bulan terakhir tingkat produksi perusahaan selalu tidak mencukupi sehingga perusahaan beberapa kali harus menolak permintaan yang datang. Jumlah produksi dan penjualan produk kerupuk ikan lele Clipss Catfish Chips dalam kurun waktu lima bulan terahir pada kondisi aktual atau sebelum pengembangan dapat dilihat di Gambar 3.

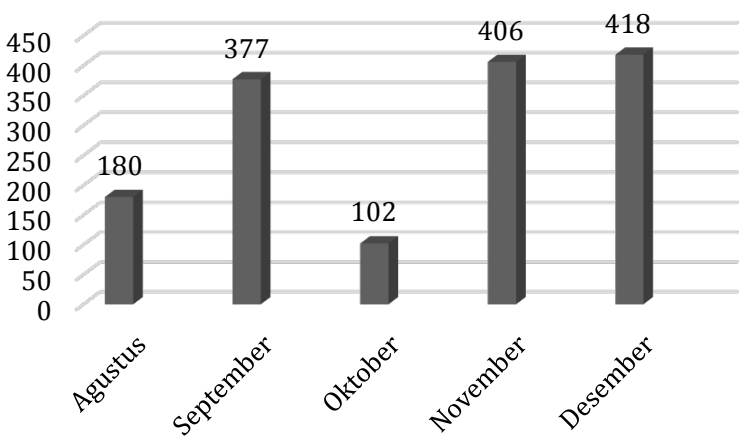

Gambar 3. Jumlah Produksi dan Penjualan Unit Usaha Clipss Catfish Chips Tahun 2019

Sumber: Clipss Catfish Chips, Agustus - Desember 2019

Berdasarkan Gambar 3 dapat dilihat bahwa penjualan perusahaan dalam kurun lima bulan terakhir cenderung meningkat dengan tingkat penjualan yang sama atau mengikuti tingkat produksi yang dimiliki. Oleh karena itu, unit usaha Clipss Catfish Chips berencana mengembangkan usaha dengan menambah kapasitas produksi sehingga didapatkan volume hasil produksi sebanyak 1560 kemasan kerupuk ikan lele setiap bulan. Jumlah tersebut bisa didapat dengan menambah penggunaan mesin produksi modern dalam proses penggorengan serta melakukan penambahan jam kerja menjadi 182 jam kerja dalam sebulan melalui penerapan jadwal produksi yang dilaksanakan setiap hari Senin sampai Sabtu pukul 08.00 - 16.00 WIB dalam 26 hari setiap bulan dengan satu karyawan produksi.

Penambahan kapasitas produksi usaha juga diiringi dengan pembuatan legalitas atau surat izin usaha yang dapat membuat realisasi pengembangan usaha berjalan lebih optimal.

Kesuksesan usaha dipengaruhi banyak faktor, salah satunya penentuan lokasi usaha yang tepat. Kebutuhan ekspansi usaha merupakan salah satu faktor penting untuk memilih suatu lokasi usaha (Handoko 2000). Menurut Soekartawi (2007), pengusaha agroindustri harus bisa menguasai teknologi untuk meningkatkan nilai tambah hasil olahan pertanian. Terlebih, ketika teknologi mengalami kemajuan maka efisiensi tenaga kerja akan meningkat sehingga tenaga kerja dapat menghasilkan output yang lebih banyak (Mankiw 2007).

Pemindahan lokasi usaha, penggunaan teknologi produksi modern serta pembuatan legalitas perusahaan tentu membutuhkan biaya investasi yang cukup besar. Oleh sebab itu, untuk mengetahui rencana pengembangan usaha layak atau tidak untuk dijalankan diperlukan penilaian investasi jangka panjang melalui analisis kelayakan.

Berdasarkan yang telah dipaparkan di atas maka tujuan penelitian ini adalah :

1. Menganalisis kelayakan non finansial pengembangan usaha kerupuk ikan lele Clipss Catfish Chips.

2. Menganalisis kelayakan finansial pengembangan usaha kerupuk ikan lele Clipss Catfish Chips.

3. Menganalisis tingkat batas perubahan yang masih bisa ditolerir pada tingkat kelayakan jika terjadi penurunan jumlah produksi dan peningkatan biaya produksi pada usaha kerupuk ikan lele Clipss Catfish Chips.

Penelitian ini dibatasi dalam cakupan analisis kelayakan pengembangan usaha dari usaha pengolahan kerupuk ikan lele "Clipss Catfish Chips" di Kota Bogor. Pengembangan usaha tersebut berupa penambahan kapasitas produksi yang meliputi pengadaan mesin produksi dan pemindahan lokasi produksi. Dalam realisasi pengembangan usaha, perusahaan juga melakukan pengurusan legalitas perusahaan 
meliputi sertifikasi PIRT, Halal, hak cipta merek, dan lain sebagainya

\section{METODE}

\section{LOKASI DAN WAKTU PENELITIAN}

Penelitian ini dilakukan di rumah produksi milik unit usaha Clipss Catfish Chips yang terletak di Kecamatan Bogor Barat, Kota Bogor, Jawa Barat. Pemilihan lokasi dilakukan secara purposive dengan pertimbangan Clipss Catfish Chips adalah usaha skala mikro yang bergerak di bidang pengolahan kerupuk ikan khususnya ikan lele dan sedang berencana melakukan pengembangan pada usahanya. Kegiatan pengumpulan data penelitian dilakukan pada bulan November 2019 hingga bulan Maret 2020.

\section{JENIS DAN SUMBER DATA}

Data yang digunakan dalam penelitian ini meliputi data primer dan data sekunder. Data primer diperoleh melalui pihak-pihak terkait yaitu pemilik usaha merangkap karyawan usaha berjumlah 3 orang, karyawan usaha 2 orang, warga sekitar 2 orang, dan mitra reseller 3 orang. Pengambilan data primer juga dilakukan pada orang di luar perusahaan dengan tujuan agar data yang didapat lebih valid dan objektif mengingat peneliti merupakan salah satu pemilik usaha. Sumber data sekunder berasal dari berbagai literatur baik dari buku maupun internet, mengenai hasil publikasi data dari lembaga dan instansi terkait yang relevan dengan penelitian.

\section{METODE PENGOLAHAN DAN ANALISIS DATA}

Pada analisis non finansial, aspek yang dikaji meliputi aspek pasar, aspek teknis, aspek manajemen dan hukum, aspek sosial, ekonomi, dan budaya, serta aspek lingkungan. Analisis kelayakan non finansial dilakukan dengan dua metode yaitu kuantitatif dengan skala likert dan kualitatif dengan deskriptif.

Penggunaan analisis kuantitatif pada aspek non finansial bertujuan untuk mempermudah dalam menganalisis dan mengambil kesimpulan kelayakan karena aspek non finansial cenderung bersifat subjektif. Analisis kuantitatif dilakukan dengan cara penilaian skor kelayakan berdasarkan skala dari satu sampai lima (1 - 5). Pilihan jawaban disusun berjenjang dari pilihan sangat tidak setuju (1) sampai sangat setuju (5). Perhitungan nilai total masing-masing atribut dari setiap aspek dilakukan dengan menjumlahkan seluruh skor yang diperoleh dan membaginya dengan jumlah item yang diteliti, yang kemudian dikalikan dengan 100 persen, sehingga akan menghasilkan skor kelayakan dalam bentuk persen. Aspek-aspek non finansial dikatakan layak jika menghasilkan skor kelayakan diantara 51 persen - 100 persen dan dikatakan tidak layak jika menghasilkan skor kelayakan diantara 1 persen 50 persen (Nazir 2005).

Pada analisis aspek finansial, analisis dilakukan secara kuantitatif menggunakan empat kriteria investasi yaitu Net Present Value, Net Benefit Cost Ratio, Internal Rate of Return dan Payback Period serta analisis switching value.

\section{Net Present Value}

Net Present Value atau manfaat bersih adalah nilai sekarang dari arus pendapatan yang ditimbulkan oleh penanaman investasi. Nilai NPV dapat dihitung dengan menggunakan rumus :

$$
N P V=\sum_{t=1}^{n} \frac{B t-C t}{(1+i)^{t}}
$$

Dimana:

NPV $=$ Net Present Value $(\mathrm{Rp})$

$\mathrm{Bt}=$ Benefit atau manfaat pada tahun ke-t

$\mathrm{Ct}=$ Cost atau biaya pada tahun ke- $\mathrm{t}$

i = Suku bunga yang berlaku

$\mathrm{n} \quad=$ Umur ekonomis proyek

$\mathrm{t} \quad=$ Tahun kegiatan bisnis

\section{Net Benefit Cost Ratio}

Net Benefit Cost Ratio adalah rasio aktivitas dari manfaat bersih bernilai positif dengan manfaat bersih yang bernilai negatif. Secara matematis Net Benefit-Cost Ratio dapat dirumuskan sebagai berikut :

$$
N e t \frac{B}{C}=\frac{\frac{\sum_{t=1}^{n} B_{t}-C_{t}}{(1+i)^{t}}}{\frac{\sum_{t=1}^{n} B_{t}-C_{t}}{(1+i)^{t}}}=>\frac{\left[B_{t}-C_{t}\right]>0}{\left[B_{t}-C_{t}\right]<0}
$$

Dimana:

$\mathrm{B} t=$ Penerimaan yang disebabkan adanya investasi pada tahun ke- $t$ 
$\mathrm{C} t=$ Biaya tahunan yang disebabkan adanya investasi pada tahun ke- $t$

$i \quad=$ Tingkat suku bunga ( persen)

$t \quad=$ Umur proyek suatu usaha $(t=1,2,3, \ldots, \mathrm{n})$

$\frac{1}{(1+i)^{t}}=$ Discount Factor (DF) pada tahun ke-t

\section{Internal Rate of Return}

Internal Rate Return (IRR) adalah tingkat rata-rata keuntungan tahunan yang dinyatakan dalam satuan persen (\%). Berikut adalah rumus dari IRR:

$$
\mathrm{IRR}=\mathrm{i}_{2}+\frac{N P V_{1}}{N P V_{2}-N P V_{1}}\left(\mathrm{i}_{2}-\mathrm{i}_{1}\right)
$$

Dimana:

$\mathrm{i}_{1}=$ Discount rate untuk menghasilkan NPV positif

$\mathrm{i}_{2}=$ Discount rate untuk menghasilkan NPV negatif

$\mathrm{NPV}_{1}=\mathrm{NPV}$ yang bernilai positif

$\mathrm{NPV}_{2}=\mathrm{NPV}$ yang bernilai negatif

\section{Payback Period}

Payback Period (PP) merupakan jangka waktu yang diperlukan untuk membayar kembali pengeluaran investasi suatu usaha. Semakin cepat kemampuan suatu usaha mengembalikan biayabiaya yang telah dikeluarkan dalam investasi usaha maka usaha tersebut semakin layak. Rumus yang digunakan adalah:

$$
P P=\frac{\mathrm{I}}{\mathrm{AB}}
$$

Keterangan :

I = Besarnya biaya investasi yang diperlukan

$\mathrm{Ab}=$ Manfaat bersih yang dapat diperoleh pada setiap tahunnya

\section{Analisis Switching Value}

Analisis Switching Value merupakan perhitungan untuk mengukur perubahan maksimum dari perubahan suatu komponen inflow (penurunan harga output, penurunan produksi) atau perubahan komponen outflow (peningkatan harga input atau peningkatan biaya produksi), yang masih dapat ditolerir oleh suatu bisnis (Nurmalina et al. 2014). Untuk dapat mengukur perubahan yang terjadi maka perlu diasumsikan bahwa perubahan-perubahan yang terjadi itu hanya pada satu bagian variabelnya saja, sedangkan yang lainya dianggap tetap (ceteris paribus).

\section{HASIL DAN PEMBAHASAN}

\section{GAMBARAN UMUM PERUSAHAAN}

Clipss Catfish Chips merupakan unit usaha agribisnis berskala mikro yang bergerak di bidang industri makanan, khususnya pengolahan kerupuk dari hasil perikanan budidaya dan perikanan tangkap. Clipss Catfish Chips memiliki visi utama yaitu menjadi perusahaan level dunia yang mampu memberi nilai tambah pada komoditas ikan lele dari on farm hingga off farm. Usaha ini didirikan oleh Bapak Dwi Kurniawan bersama ketiga orang rekannya yang masih berstatus mahasiswa. Sebelum mendirikan usaha pengolahan kerupuk ikan ini, Bapak Dwi beserta ketiga rekannya terlebih dahulu menekuni usaha budidaya ikan lele. Pada awal tahun 2018 Bapak Dwi mengikuti kegiatan pelatihan pengolahan hasil panen ikan lele yang kemudian dari hasil kegiatan tersebut, serta dengan melihat peluang pasar dari produk olahan ikan yang besar, di tahun yang sama Bapak Dwi Kurniawan beserta ketiga rekannya memutuskan untuk mengubah usaha budidaya ikan lele menjadi usaha pengolahan kerupuk ikan lele

\section{ASPEK NON FINANSIAL}

Analisis kelayakan aspek non finansial usaha dilakukan dalam kondisi pengembangan yaitu kondisi setelah usaha pengolahan kerupuk ikan lele melakukan penambahan kapasitas produksi. Aspek non finansial yang dikaji terdiri dari aspek pasar, aspek teknis, aspek manajemen dan hukum, aspek sosial, ekonomi,dan budaya, serta aspek lingkungan.

\section{Aspek Pasar}

Penentuan permintaan dilakukan dengan menggunakan metode permintaan industri dan metode rasio rantai (Sucipto 2011). Kajian variabel permintaan dan penawaran dengan metode permintaan industri dilakukan dengan cara menganalisis market potential pada target pasar industri restoran di Kota Bogor. Jumlah restoran di Kota Bogor tercatat sebanyak 162 restoran (BPS 2017). Dengan strategi penjualan 
memasok 10 kemasan di masing-masing restoran akan didapat potensi pasar sebanyak 1.620 kemasan setiap bulannya. Jumlah tersebut melebihi kapasitas penawaran perusahaan dalam kondisi pengembangan yaitu sebanyak 1.560 kemasan.

Metode rasio rantai dilakukan pada target pasar menurut aspek geografis dan demografis yaitu konsumen yang tinggal di daerah Kota Bogor dan berjenis kelamin laki- laki serta perempuan dengan rentang usia 15 - 35 tahun sebanyak 361.087 orang dengan pendapatan per kapita sebesar Rp 29.616 (BPS 2017 Diolah). Dengan asumsi pembelian sebanyak satu kali dalam satu tahun maka market potential dari usaha ini adalah sebesar Rp 29.616 x 361.087 = Rp 10.693.952.592 .Pada periode penjualan usaha dalam kondisi pengembangan selama satu tahun diproyeksikan unit usaha Clipss Catfish Chips mendapatkan omzet sebesar Rp 280.800.000. Maka market share yang dimiliki oleh unit usaha Clipss Catfish Chips adalah sebesar (Rp 280.800.000 / Rp 10.693.952.592) x 100 persen $=2,63$ persen. Perhitungan tersebut menunjukkan bahwa permintaan terhadap produk kerupuk ikan lele Clipss Catfish Chips baru mencukupi 2,63 persen dari total pasar potensial yang ada di Kota Bogor.

Saat ini usaha memiliki dua varian rasa produk kerupuk ikan lele yaitu rasa "Original" dan "Barracuda" dengan lima saluran pemasaran yaitu toko, restoran, reseller individu, reseller kepanitiaan, dan konsumen akhir. Proses promosi dan penjualan dilakukan secara online dan offline menggunakan Instagram, whatsapp, shopee, brosur, dan event atau bazaar.

Berdasarkan hasil analisis kelayakan aspek pasar secara kuantitatif diperoleh persentase nilai kelayakan aspek pasar sebesar 80 persen sehingga dapat dikatakan layak karena menghasilkan skor kelayakan lebih dari 50 persen.

\section{Aspek Teknis}

Lokasi usaha pengolahan kerupuk ikan lele pada kondisi pengembangan berlokasi di Taman Dramaga Indah, Kota Bogor berbentuk rumah sederhana bertipe 21. Perusahaan memenuhi kebutuhan bahan bakunya melalui toko grosir yang berjarak 4,8 kilometer, pasar tradisional yang berjarak 2,3 kilometer, dan toko kecil yang berjarak 10 meter dari lokasi usaha.

Proses produksi yang dijalankan meliputi proses penyiapan bahan baku, pengadonan, pencetakan, penggorengan, penirisan, dan pengemasan. Proses produksi dilakukan menggunakan peralatan dapur sederhana dengan bantuan mesin produksi modern seperti mesin penipis elektrik, mesin hand sealer, serta mesin spinner dan mesin deep fryer yang baru ditambahkan pada kondisi pengembangan usaha.

Pada kondisi pengembangan usaha Clipss Catfish Chips menargetkan produksi kerupuk ikan lele dalam sebulan mampu mencapai 1560 kemasan atau setara dengan 109,2 kg kerupuk. Jumlah tersebut bisa didapat dengan melakukan penambahan jam kerja menjadi 182 jam kerja dalam sebulan melalui optimalisasi lokasi rumah produksi yang baru serta dengan menambah penggunaan mesin produksi modern dalam proses penggorengan agar bisa memproduksi secara optimal sesuai kapasitas produksinya. Total 182 jam kerja dalam sebulan didapat melalui jadwal produksi karyawan usaha yang dilaksanakan setiap hari Senin sampai Sabtu pukul 08.00 16.00 WIB dalam 26 hari setiap bulan dengan satu karyawan produksi.

Berdasarkan hasil analisis kelayakan aspek teknis secara kuantitatif diperoleh persentase nilai kelayakan aspek pasar sebesar 74,16 persen sehingga dapat dikatakan layak karena menghasilkan skor kelayakan lebih dari 50 persen.

\section{Aspek Manajemen dan Hukum}

Pada aspek manajemen, tenaga kerja yang bekerja di unit usaha Clipss Catfish Chips berjumlah tujuh orang dimana empat orangnya juga berstatus sebagai pemilik usaha. Masing masing pemilik usaha merangkap jabatan sebagai direktur utama dan manajer sumber daya manusia, manajer keuangan dan staf pengadaan atau inventory control, manajer pemasaran dan staf pengemasan, serta manajer produksi. Fenomena rangkap jabatan dilakukan oleh perusahaan pada kondisi aktual bertujuan untuk menekan biaya gaji karyawan.

Mayoritas tenaga kerja masih berstatus sebagai mahasiswa di Institut Pertanian Bogor 
(IPB). Dalam proses rekrutmen tenaga kerja diterapkan beberapa kriteria dan persyaratan untuk bisa bekerja seperti pada aspek produksi dengan jabatan staf dapur, dibutuhkan tenaga kerja dengan kriteria yaitu ibu rumah tangga, memiliki rentang usia 30 - 45 tahun, memiliki pengalaman bekerja di dapur minimal tiga tahun, dan berdomisili di sekitar lokasi usaha. Adapun untuk jabatan lainnya hanya memiliki satu kriteria yaitu memiliki keahlian di bidang yang ditekuni. Struktur organisasi usaha dapat dilihat di Gambar 4.

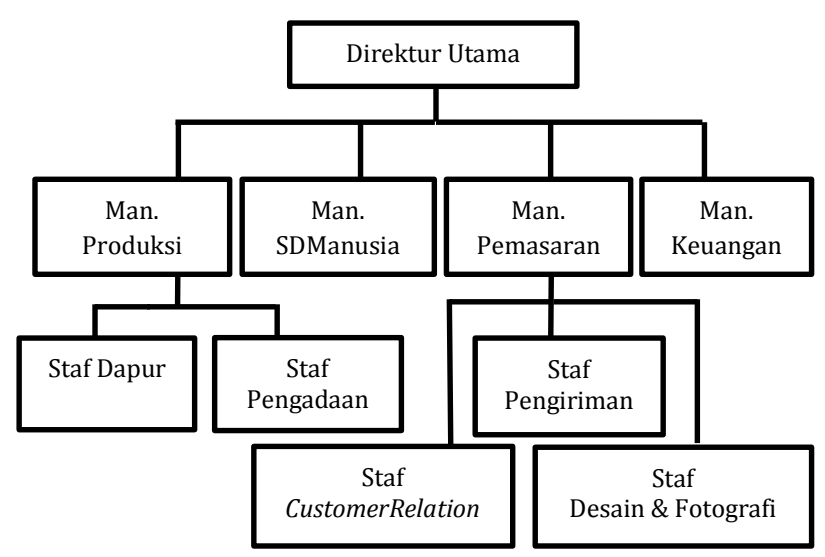

Gambar 4. Struktur Usaha Clipss Catfish Chips Sumber : Clipss Catfish Chips, 2019

Pada aspek hukum, dalam kondisi aktual usaha tidak memiliki izin apapun. Saat ini dalam realisasi pengembangan usaha pemilik usaha terus melengkapi perizinan yang dibutuhkan oleh perusahaan. Saat ini perusahaan telah memiliki Izin Mendirikan Bangunan (IMB), izin Surat Keterangan Domisili Usaha (SKDU), dan sertifikasi Pangan Industri Rumah Tangga (PIRT), serta dalam proses pengurusan Surat Pernyataan Kesanggupan Pengelolaan dan Pemantauan Lingkungan Hidup (SPPL). Kedepannya seiring proses pengembangan usaha, perusahaan juga akan melengkapi izin-izin lain yang dibutuhkan perusahaan seperti sertifikasi Halal MUI, sertifikasi Hazard Analisys Critical Control Point (HACCP), mematenkan merek, serta melakukan pembentukan badan usaha Persekutuan Komanditer (CV) yang meliputi pendirian akta perusahaan, Nomor Pokok Wajib Pajak (NPWP) perusahaan, serta Nomor Induk Berusaha (NIB).

Berdasarkan hasil analisis kelayakan aspek manajemen dan hukum secara kuantitatif diperoleh persentase nilai kelayakan aspek pasar sebesar 62,85 persen sehingga dapat dikatakan layak karena menghasilkan skor kelayakan lebih dari 50 persen.

\section{Aspek Sosial, Ekonomi, dan Budaya}

Dari aspek sosial, berjalannya usaha disambut dengan hangat dan tanpa penolakan oleh masyarakat sekitar. Pada kondisi pengembangan, halaman depan rumah produksi yang cukup luas setiap pagi sering kali dijadikan tempat berkumpul oleh tukang ojek dan warga sekitar lainnya. Warga sekitar juga sering datang ke lokasi usaha untuk sekedar menyapa, memberikan saran terkait lingkungan dan membeli produk.

Dari aspek ekonomi, perusahaan turut membantu membuka lapangan pekerjaan dan mengurangi angka pengangguran di sekitar lokasi usaha. Sampai saat ini perusahaan pernah mempekerjakan sembilan orang warga sekitar sebagai tenaga kerja tetap dan dua orang sebagai tenaga kerja tidak tetap. Dari aspek budaya, keberadaan perusahaan tidak bertentangan dengan budaya yang telah berkembang di masyarakat sekitar lokasi usaha. Menurut Ketua RW, berdirinya usaha dapat membawa pengaruh positif dengan menjadi contoh bagi warga sekitar lokasi usaha untuk menjadi wirausaha yang mandiri.

Berdasarkan hasil analisis kelayakan aspek sosial, ekonomi, dan budaya secara kuantitatif diperoleh persentase nilai kelayakan aspek sosial, ekonomi, dan budaya sebesar 61,28 persen sehingga dapat dikatakan layak karena menghasilkan skor kelayakan lebih dari 50 persen.

\section{Aspek lingkungan}

Dari aspek limbah yang dihasilkan beserta pengelolaannya, perusahaan menghasilkan beberapa jenis limbah yang berpotensi mengganggu lingkungan dan perusahaan telah melakukan proses pengelolaan limbah tersebut. Perusahaan bekerjasama dengan petugas kebersihan dan Bank Sampah setempat untuk mengelola sampah dapur serta minyak goreng sisa.

Selain itu, perusahaan meminimalisir suara yang mengganggu dari penggunaan mesin dengan cara menggunakannya di siang hari waktu kerja serta hanya menggunakannya 1,5 jam dari total 8 
jam kerja. Dari aspek keamanan lingkungan, perusahaan telah bekerjasama dengan aparatur keamanan setempat untuk membantu menjaga keamanan lingkungan sekitar lokasi usaha. Selain itu, lokasi usaha hanya berjarak 10 meter dari pos keamanan lingkungan setempat.

Bedasarkan hasil analisis kelayakan aspek lingkungan secara kuantitatif diperoleh persentase nilai kelayakan aspek sosial, ekonomi, dan budaya sebesar 61,6 persen sehingga dapat dikatakan layak karena menghasilkan skor kelayakan lebih dari 50 persen.

\section{HASIL ANALISIS KELAYAKAN NON FINANSIAL}

Analisis kelayakan aspek non finansial yang dilakukan secara kualitatif secara deskriptif menghasilkan hasil yang sama dengan analisis kelayakan yang dilakukan secara kuantitatif dengan metode skala likert pada seluruh aspek penilaiannya yaitu aspek pasar, aspek teknis, aspek manajemen dan hukum, aspek sosial, ekonomi, dan budaya, serta aspek lingkungan.

Analisis kuantitatif pada kondisi pengembangan, menghasilkan nilai kelayakan aspek pasar sebesar 80 persen, aspek teknis sebesar 74,16 persen, aspek manajemen dan hukum sebesar 62,85 persen, aspek sosial, ekonomi, dan budaya sebesar 61,28 persen serta aspek lingkungan sebesar 61,6 persen. Sehingga didapatkan rata-rata skor analisis kelayakan non finansial sebesar 67,98 persen dan dapat disimpulkan bahwa aspek non finansial Clipss Catfish Chips pada kondisi pengembangan adalah Layak, karena jumlah nilai kelayakan lebih dari 50 persen. Hasil analisis aspek non finansial secara kuantitatif dapat dilihat pada Tabel 1.

Tabel 1. Hasil Analisis Kelayakan Aspek Non Finansial Secara Kuantitatif

\begin{tabular}{lrrrr}
\hline \multicolumn{1}{c}{ Aspek } & $\begin{array}{c}\text { Rata- Persentase } \\
\text { Total } \\
\text { Skor }\end{array}$ & $\begin{array}{c}\text { rata } \\
\text { Total } \\
\text { Skor }\end{array}$ & $\begin{array}{c}\text { Tingkat } \\
\text { Kelayakan } \\
\text { (\%) }\end{array}$ & Layak \\
\hline Pasar & 32 & 4 & 80 & V \\
Teknis & 44,5 & 3,71 & 74,16 & V \\
Manajemen dan & & & & \\
$\begin{array}{l}\text { Hukum } \\
\text { Sosial, Ekonomi, } \\
\text { dan Budaya }\end{array}$ & 22 & 3,14 & 62,8 & V \\
Lingkungan & 15,32 & 3,06 & 61,28 & v \\
\hline Rata - rata & 15,4 & 3,08 & 61,6 & V \\
\hline
\end{tabular}

\section{ASPEK FINANSIAL}

\section{Analisis Arus Pengeluaran (Outflow)}

Arus pengeluaran pada kegiatan usaha Clipss Catfish Chips meliputi biaya investasi dan re-investasi serta biaya operasional. Pada perhitungan biaya investasi dalam analisis arus tunai (cashflow) unit usaha Clipss Catfish Chips terdiri dari dua kondisi barang investasi yaitu barang lama dan baru. Barang investasi lama berarti barang-barang investasi yang dibeli perusahaan pada kondisi aktual perusahaan dan dinilai dengan nilai sisa setelah satu tahun bisnis berjalan. Barang investasi baru berarti barangbarang investasi yang baru dibeli perusahaan untuk merealisasikan proses pengembangan seperti mesin penggorengan otomatis (deep fryer), mesin peniris minyak (spinner), mesin hand sealer, perizinan dan sertifikasi perusahaan, serta beberapa peralatan dapur lainnya. Total biaya investasi yang ditanamkan oleh perusahaan yaitu sebesar Rp 70.361.000.

Biaya operasional merupakan keseluruhan biaya yang dikeluarkan dalam menghasilkan produk pada kegiatan proses produksi kerupuk ikan lele di unit usaha Clipss Catfish Chips. Biaya operasional terdiri dari dua komponen yakni, biaya tetap dan biaya variabel (Nurmalina et al, 2014). Biaya tetap pada usaha pengolahan kerupuk ikan lele Clipss Catfish Chips yaitu sewa rumah produksi, gaji karyawan perusahaan, transportasi, listrik, dan air. dan perhitungan penyusutan aset per tahun. Sedangkan biaya variabel pada usaha pengolahan kerupuk ikan lele Clipss Catfish Chips ini meliputi biaya pembelian bahan baku, kemasan, sambal, minyak, dan isi ulang gas. Pada tahun pertama sampai tahun kedelapan komponen biaya operasional memiliki biaya yang sama selama umur bisnis berlangsung yaitu sebesar Rp 258.744.038,00- dengan nominal biaya tetap sebesar Rp 140.662.742 dan biaya variabel sebesar Rp 118.081.296.

\section{Analisis Arus Penerimaan (Inflow)}

Arus penerimaan pada kegiatan usaha Clipss Catfish Chips meliputi hasil penjualan produk kerupuk, nilai sisa investasi, serta dana bantuan atau hibah. Setiap bulannya diproyeksikan perusahaan dapat menghasilkan sebanyak 
1.560 kemasan yang jika dikonversikan dalam periode satu tahun maka didapatkan 18.720 kemasan kerupuk ikan lele. Dengan asumsi ratarata harga jual produk adalah Rp 15.000, maka setiap tahunnya usaha mendapat penerimaan dari penjualan produk sebesar Rp 280.800.000. Selain dari penjualan hasil produksi, pada tahun pertama perusahaan menggunakan dana bantuan atau hibah yang didapat dari pemerintah Kementrian Pemuda dan Olahraga sebesar Rp 15.000.000 sehingga total penerimaan usaha di tahun pertama meningkat sebesar Rp 295.800.000.

Perusahaan memiliki beberapa investasi baik yang berwujud maupun tidak berwujud yang memiliki umur ekonomis melebihi dari umur usahanya sehingga nilai barang tersebut memiliki nilai sisa pada akhir umur bisnis. Nilai sisa tersebut dihitung dan diperkirakan pada awal investasi sesuai kondisi barang yang ada baik barang investasi lama maupun barang investasi baru. Total nilai sisa investasi usaha pada akhir umur bisnis adalah sebesar Rp 9.697.000 sehingga total penerimaan usaha di tahun terakhir meningkat sebesar Rp 290.497.000.

\section{Proyeksi Rugi Laba}

Analisis rugi laba usaha pengolahan kerupuk ikan lele Clipss Catfish Chips dilakukan dengan pengurangan komponen total penerimaan dengan komponen biaya operasional yang terdiri dari biaya tetap dan variabel. Laba kotor yang didapat dari pengurang total penjualan dengan total biaya operasional adalah sebesar Rp 10.713.204,00-. Nominal tersebut berjumlah sama dengan nominal laba sebelum pajak karena bunga sebesar 5,02 persen tidak diikutkan dalam perhitungan dikarenakan modal yang digunakan usaha pada kondisi pengembangan ialah modal sendiri dan dana bantuan. Kriteria pajak penghasilan usaha yang digunakan adalah mengacu pada Peraturan Pemerintah Republik Indonesia Nomor 46 Tahun 2013 yang menyatakan bahwa usaha yang memiliki pendapatan kotor dibawah Rp 4.800.000.000 maka pajak yang dikenakan sebesar satu persen dari pendapatan sebelum pajak. Pajak penghasilan usaha yang harus dibayarkan oleh unit usaha Clipss Cafish Chips pada kondisi aktual ialah sebesar Rp 107.132,00Sehingga laba bersih yang didapat perusahaan pada tahun pertama hingga ke delapan adalah sebesar Rp 10.713.204,00-.

\section{Kriteria Kelayakan Investasi}

Analisis kriteria kelayakan investasi digunakan untuk mengetahui tingkat kelayakan usaha berdasarkan aspek finansial. Kriteria investasi yang digunakan adalah Net Present Value (NPV), Internal Rate of Returm (IRR), Net BenefitCost Ratio (Net B/C), dan Payback Period (PP). Dari analisis yang telah dilakukan dapat disimpulkan bahwa rencana pengembangan usaha Clipss Catfish Chips layak untuk dijalankan berdasarkan aspek finansial karena seluruh kriteria investasinya telah memenuhi syarat kelayakan. Nilai kriteria kelayakan usaha Clipss Catfish Chips dapat dilihat pada Tabel 2.

\begin{tabular}{llrl} 
Tabel 2. Hasil & \multicolumn{2}{c}{ Kriteria } \\
Usaha Clipss Catfish Chips & \multicolumn{1}{c}{$\begin{array}{c}\text { Kelayakan } \\
\text { Investasi }\end{array}$} \\
\hline Kriteria & Syarat & \multicolumn{1}{c}{ Hasil } & Nilai \\
\hline NPV & $>0$ & 58.699 .147 & Layak \\
NET B/C & $>1,00$ & 1,72 & Layak \\
IRR & $>5,02$ & 23,26 & Layak \\
PP & $<8$ & 4,12 & Layak \\
\hline
\end{tabular}

Analisis switching value dilakukan terhadap komponen-komponen yang dianggap paling mempengaruhi kelayakan usaha. Komponen yang dianggap paling mempengaruhi kelayakan usaha Clipss Catfish Chips adalah kenaikan harga bahan baku ikan, kenaikan harga kemasan produk, dan penurunan jumlah produksi perusahaan.

Kenaikan harga bahan baku ikan dapat terjadi karena salah satu bahan baku ikan yang dipakai adalah ikan laut yang ketersediaan dan harga belinya bergantung pada kondisi musim yang terus berubah. Selain itu, harga bahan baku ikan lele juga cenderung berbeda antar penjualnya. Kenaikan harga kemasan dapat terjadi jika mitra produsen kemasan berhenti menyediakan suplai kemasan kepada perusahaan yang mengakibatkan perusahaan harus bekerjasama dengan mitra produsen kemasan lain yang cenderung mematok harga kemasan lebih mahal. Komponen biaya kemasan sendiri merupakan komponen yang menggunakan biaya terbesar dalam arus pengeluaran variabel usaha. Adapun penurunan jumlah produksi dapat terjadi dikarenakan turunnya penjualan perusahaan serta kemungkinan 
gagalnya proses produksi disaat masa pelatihan karyawan mengingat menurut pemilik usaha hingga saat ini perusahaan kesulitan untuk mendapatkan karyawan produksi yang tepat sehingga kemungkinan turn over karyawan produksi kedepannya cukup tinggi. Perubahan komponenkomponen tersebut akan mempengaruhi penerimaan usaha dan kemudian mempengaruhi kelayakan usaha. Hasil analisis switching value usaha Clipss Catfish Chips dapat dilihat pada Tabel hasil analisis switching value usaha Clipss Catfish Chips dapat dilihat pada Tabel 3.

Tabel 3. Hasil Analisis Switching Value Usaha Clipss Catfish Chips

\begin{tabular}{lr}
\hline Komponen Perubahan & \multicolumn{1}{c}{$\begin{array}{c}\text { Batas } \\
\text { Perubahan } \\
\text { (\%) }\end{array}$} \\
\hline Peningkatan Harga Ikan & 36,99 \\
Peningkatan Harga Kemasan & 24,27 \\
Penurunan Jumlah Produksi & 5,58 \\
\hline
\end{tabular}

Batas maksimum peningkatan harga ikan adalah sebesar 36,99 persen dengan hasil nilai NPV sebesar Rp 6.068 yang berarti usaha ini masih layak dijalankan dengan batas perubahan atau peningkatan harga ikan sebesar 36,99 persen. Selain itu, batas maksimum untuk peningkatan harga kemasan adalah sebesar 24,27 persen dengan nilai NPV sebesar Rp 17.401 dan batas untuk penurunan jumlah produksi adalah 5,58 persen dengan nilai NPV sebesar Rp 62.506. Sehingga dapat disimpulkan bahwa variabel penurunan jumlah produksi lebih sensitif daripada dua variabel lainnya yaitu kenaikan harga bahan baku ikan dan kemasan.

\section{SIMPULAN DAN SARAN}

\section{SIMPULAN}

Berdasarkan hasil penelitian mengenai analisis kelayakan pengembangan usaha pengolahan kerupuk ikan lele "Clipss Catfish Chips" di Kota Bogor, didapatkan simpulan sebagai berikut:

1. Berdasarkan hasil analisis kelayakan aspek non finansial yang meliputi aspek pasar, aspek teknis, aspek manajemen dan hukum, aspek sosial, ekonomi, dan budaya, serta aspek lingkungan, pengembangan usaha pengolahan kerupuk ikan lele Clipss Catfish Chips layak untuk dijalankan.

2. Berdasarkan hasil analisis kelayakan aspek finansial menggunakan empat kriteria investasi yaitu Net Present Value, Net Benefit Cost Ratio, Internal Rate of Return, , dan Payback Period, pengembangan usaha pengolahan kerupuk ikan lele Clipss Catfish Chips layak untuk dijalankan.

3. Berdasarkan hasil analisis switching value menggunakan tiga variabel perubah, variabel penurunan jumlah produksi memiliki tingkat sensitivitas yang lebih tinggi daripada variabel kenaikan harga ikan dan variabel kenaikan harga kemasan.

\section{SARAN}

Berdasarkan simpulan dan hasil penelitian yang telah diperoleh, saran yang dapat direkomendasikan untuk unit usaha Clipss Catfish Chips yaitu:

1. Unit usaha Clipss Catfish Chips dapat melanjutkan realisasi pengembangan usaha yang berupa penambahan kapasitas produksi meliputi pengadaan mesin produksi yang lebih modern dan pemindahan lokasi rumah produksi.

2. Perusahaan sebaiknya segera melengkapi legalitas atau surat izin usaha agar proses pengembangan usaha dapat berjalan optimal.

3. Demi mencegah penurunan jumlah produksi, usaha Clipss Catfish Chips dapat meminimalisir turn over atau keluar masuknya karyawan produksi. Perusahaan juga dapat melakukan penelitian lebih lanjut terkait penetapan strategi pemasaran yang tepat pada kondisi pengembangan usaha.

\section{DAFTAR PUSTAKA}

[BPS] Badan Pusat Statistika. 2014. Ringkasan Eksekutif Pengeluaran Dan Konsumsi Penduduk Indonesia Berdasarkan Hasil Susenas Maret 2014. Jakarta (ID) : BPS Nasional

[BPS] Badan Pusat Statistika. 2015. Ringkasan Eksekutif Pengeluaran Dan Konsumsi Penduduk Indonesia Berdasarkan Hasil 
Susenas Maret 2015. Jakarta (ID) : BPS Nasional

[BPS] Badan Pusat Statistika. 2016. Ringkasan Eksekutif Pengeluaran Dan Konsumsi Penduduk Indonesia Berdasarkan Hasil Susenas Maret 2016. Jakarta (ID) : BPS Nasional

[BPS] Badan Pusat Statistika. 2017. Ringkasan Eksekutif Pengeluaran Dan Konsumsi Penduduk Indonesia Berdasarkan Hasil Susenas Maret 2017. Jakarta (ID) : BPS Nasional

[BPS]Badan Pusat Statistika. 2018. Pengeluaran Untuk Konsumsi Penduduk Indonesia Berdasarkan Hasil Susenas Maret 2018. Jakarta (ID) : BPS Nasional

[KKP] Kementerian Kelautan dan Perikanan Republik Indonesia. 2018. Perkembangan Produksi Perikanan Budidaya Menurut Komoditas Utama. Jakarta (ID) : Kementerian Kelautan dan Perikanan.

[KKP] Kementerian Kelautan dan Perikanan Republik Indonesia. 2015. Produktivitas Perikanan Indonesia. Jakarta (ID) : Kementerian Kelautan dan Perikanan.

Budidyanto, B. 2016. Peta Sentra Produksi Perikanan Budidaya. Jakarta Kementerian Kelautan dan Perikanan

Handoko, T.H. 2000. Dasar-dasar Manajemen Produksi dan Operasi. Yogyakarta: BPFE.

Kusumaningrum. I, dan A. N. Asikin. 2016. Karakteristik Kerupuk Ikan Fortifikasi Kalsium Dari Tulang Ikan Belida. JPHPI(journal.ipb.ac.id/index.php/jphpi). $19(3)$ : 233-240.

Mankiw, N.G. 2007. Makroekonomi. Jakarta (ID): Erlangga.

Nazir, M. 2005. Metode Penelitian. Bogor (ID): Ghalia Indonesia.

Nurmalina R, Sarianti T, Karyadi A. 2014. Ed ke-3. Studi Kelayakan Bisnis. Bogor (ID): IPB Press.

Soekartawi. 2007. Beberapa Hal Yang Harus Diperhatikan Dalam Melakukan Analisis Sistem Agroindustri Terpadu [jurnal]. Jurnal agribisnis dan ekonomi pertanian. 1(2):31-47.
Sucipto, A. 2011. Studi Kelayakan Bisnis. Malang (ID): UIN Maliki Press.

Triyanti, R. dan Safitri, N. 2012. Kajian Pemasaran Ikan Lele (Clarias Sp) Dalam Mendukung Industri Perikanan Budidaya [jurnal]. Jurnal Sosek KP. 7(2): 177-191.

Valin, H.S. dkk. 2014. The future of food demand: understanding differences in global economic models. J. Agricultural Economics. 45(1): 51-67.

Zulfahmi. A.N, F. Swastawati dan Romadhon. 2014. Pemanfaatan Daging Ikan Tenggiri (Scomberomorus commersoni) Dengan Konsentrasi Yang Berbeda pada Pembuatan Kerupuk Ikan. Jurnal Pengolahan dan Bioteknologi Hasil Perikanan. 3(4) : 133-139. 